\title{
Rural tourism (agritourism) of the Rostov region: condition, problems and development trends
}

\author{
Lyudmila Kazmina ${ }^{1, *}$, Vadim Makarenko ${ }^{1}$,Valeria Provotorina ${ }^{1}$ and Elena Shevchenko ${ }^{1}$ \\ ${ }^{1}$ Don State Technical University, 1, Gagarina Sq., 344000, Rostov-on-Don, Russia
}

\begin{abstract}
The present article is concerned with condition, problems and development trends of agritourism of the Rostov region. This article provides a review of materials related to the research problem; regions of the Rostov region are considered from the perspective of agritourism development. Moreover, typing of agritourism clusters is carried out and social and economic impact of their performance is estimated.
\end{abstract}

\section{Introduction}

Today agritourism is one of the most future-oriented kinds of tourism. Agritourism routs are usually laid through rural territories, where other kinds of tourism (educational, business, etc.) are not as developed as they are in towns and cities.

It is agritourism that represents a growth area for rural economics. This kind of tourism is able to increase employment opportunities, to become a trigger for inflow of investments to enter rural territories resulting in enriching local citizens and social and sustainable development.

Agritourism development may also promote rural infrastructure optimization, transport network evolution, building of hotels, catering establishments, family entertainment centres, etc. Not least important is positive impact of agritourism on agriculture.

The purpose of the present article is a comprehensive assessment of agritourism of the Rostov region, identification of problems and determination of its development trends.

Main tasks of the research:

- to analyze the research basis of the issue of agritourism condition and problems;

- to consider rural territories of the Rostov region in the light of agritourism development;

- to carry out a typing of recreation clusters of agritourism of the region and to access costs associated with their organization when developing several types of business projects;

- to justify social and economic effect of functioning of typical clusters.

\footnotetext{
*Corresponding author: kafedra_tiig@mail.ru
} 


\section{Materials and methods}

The present research is based on works of foreign and Russian scientists in the sphere of agritourism. The term "agritourism" belongs to a French researcher F. Muane, 2007. Scientific literature on this issues points that agritourism is a factor for sustainable development of rural territories, L.V. Evgrafova, A.Z. Ismailova, V.L. Kalinichev, 2020 [1]. Research methods of agritourism with reference to regional specifics are discussed in works of the following authors: S. Karampela, D. Kavroudakis, T. Kizos, 2019 (Greece practices) [2], T.Y. Dewanti, D. Susiloningtyas, Supriatna, 2019, (Indonesia practices) [3], S. Li, C. Li, J. Li, 2019, (Chineese practices) [4] and others. Interest of tourists in agritourism is on the rise. Data on rise in the number of tourists who are going to visit countryside are presented in academic papers of N.T. Farsani, S.S. Ghotbabadi, M. Altafi H., Choo, J.F. Petrik, [5, 6].

In the process of analyzing scientific literature it was discovered that agritourism is based on a function of specialized farms and touristic villages. This issues is reflected in works of Sueb, S. Suhadi, S. Suwarni, A. Shofiyah, D.R. Putri, E.I. Diartika, N. Rizky, V.R.A. Zahroh, K.A. Widowati, H. Choo, T. Jamal, 2019 [7,8]. It is proved that agritourism promotes sustainability of agricultural farms and, if done right, it provides them with significant economic benefits, as discussed in papers of C.Barbieri, 2013 [9], S. Sotomayor, F.X. Aguilar, 2019 [10]. Practice of involving farms into agritourism, as well as total experience of agritourism development is analyzed in works of L.O. Tugade, S. Li, C. Li, J. $\mathrm{Li}, 2019[11,12]$.

Review of researches on this issue shows that measures on promotion of touristic establishments, development of corresponding brands are essential to develop tourism, A.R.D. Liang, Y.Y. Nie, D.J. Chen, P-J. Chen, M.V. Vikhoreva, Yu.N. Malinina, V.A. Ogloblin, $2020[13,14]$.

This research is also based on provisions of papers of M. Lanfranchi, M.G. Campolo, A.M. Di Trapani, C. Giannetto, K.L. Sidali, Spitaler, G. Schamel, 2019, [15,16], where factors of tourists' satisfaction with agritouristic structures are considered and strategies for determination of their quality parameter are discovered.

Moreover, in academic papers of A. Ispas, E.N. Untaru, A.N. Candrea 2019 [17], special attention is paid to practice of smart use of natural resources in agritouristic farms.

Issues of agritourism development in view of its separate sectors are considered in works of the following authors: enotourism - R.M. Back, A.D.A. Tasci, A., 2020 [18], M. Gomez, M.A. Pratt, A. Molina, 2019 [19], tourism aimed at coffee and agroforestry - L. Hakim, D. Siswanto, B. Rahardi, H. Zayadi, 2019 [20].

Papers of L.N. Kazmina, V.S. Makarenko, V.V. Provotorina, T.N. Grigorenko, M.S. Giltsova, O.A. Mironova, 2019 [21, 22] are dedicated to prospects for further development of agritourism in Russia, in particular, in the Rostov region, with reference to formation of a tourist and recreational cluster.

Generally speaking, it may be noted that agritourism is one of the most important sectors of touristic industry representing a complex of touristic products, services and infrastructure oriented on arrangement of tours around rural territories. In the course of arrangement of agritours, tourists may see rural style of life, traditions, crafts, nature, as well as be directly involved in various aspects of life of rural people.

The following methods were used when conducting the research: look-back study, chorological method (spatial analysis of the territory), statistical data processing, comparative analysis, economic method. 


\section{Results}

The Rostov region has got all pre-requisites for agritourism development. A significant part of its territory is occupied by regions with developed agriculture, various combinations of sectors of crop and livestock farmings (central area, south and east of the region). Moreover, the territory of the region is characterized by ethnic variety, resulting in unique culture-historical traditions of local people and availability of valuable archaeological sites of various historical periods (from antique to present days).

In addition to rural territories of the region, some towns are potential objects for development of agritourism too, as many of them have historical growth from stanitsas (large Cossack villages) and preserve prints of rural style of life. It is possible to arrange agritouristic complexes on such territories, as here there is infrastructural basis (accommodation means, transport, catering establishments, public amenities, etc.).

Development of agritourism in the Rostov region is also able to promote renewal of a touristic rout "Don's Silver Horseshoe", as it originally includes not only towns of the region, but also key touristic rural territories. Arrangement of agritouristic routs is expected to become a basis of development of so called Big, Middle and Small Horseshoes, because the word "horseshoe" is connected with rural territory by association and may become a brand of agritourism.

It is assumed that directions for the development of agritourism shall be an integral part of Tourism Development Programs of the region and administrative areas followed by potential positive momentum of development supported by local authorities. But the analysis showed that Tourism Development Programs are currently active just in 16 of 43 districts of the region. At that, agritourism, which is able to become a leading type of tourism, is not mentioned in the Programs.

Targeted development of agritourism should be focused on formation of clusters, combining touristic facilities, touristic services, and transport and so on within a specified territory. However, a cluster type should reflect specifics of the territory, available touristic resources, traditions, culture-historical peculiarities, folk art of local people, etc.

Typing of high-potential touristic resources of the region's districts is carried out based on the research (see Table1). Moreover, measures, which provide for tourism boost on the specified territories (locals and residents of other districts and towns of the region), are highlighted.

Authors proposed ethnographic tourism, farm tours, hunting and fishing, food and wine, equine tourism, ecotourism and others as main clusters of agritourism. In each of highpotential clusters, newsworthy and thematic events may be arranged, geographically based master classes may be carried out too.

It should be noted that some of the specified events are delivering, being attractions for tourists (Sholokhov Spring, Tanais Day, Glorified Steppe, Cucumber Day, Day of the Chebak, Don Vine, etc).

Figure 1 shows the structure of agritourism cluster. The base is the tourist and recreational cluster, specified by the authors in the present article, dedicated to clustering of development of tourism in the territory of the Rostov region[21].

Table 1. Distribution of typical recreation clusters of agritourism to districts of the Rostov region.

\begin{tabular}{|c|c|c|c|c|c|l|}
\hline \multirow{2}{*}{ No } & \multirow{2}{*}{ Regions } & Settlements & \multirow{2}{*}{ Type } & \multicolumn{3}{|c|}{ Events } \\
\cline { 5 - 7 } & & & thematic & newsworthy & master classes \\
\hline 1 & Aksay & $\begin{array}{l}\text { Rogozhkino, } \\
\text { Elizavetinskaya }\end{array}$ & ethnographic & $\begin{array}{l}\text { Cossackdom } \\
\text { festivals, } \\
\text { hypical } \\
\text { Cossack }\end{array}$ & $\begin{array}{l}\text { reconstruction } \\
\text { recorse riding, }\end{array}$ & $\begin{array}{l}\text { horse } \\
\text { Cossack crafts }\end{array}$ \\
\hline
\end{tabular}




\begin{tabular}{|c|c|c|c|c|c|c|}
\hline & & & & stanitsas & & \\
\hline 2 & Azov & $\begin{array}{l}\text { Starocherkasskaya } \\
\text { Semibalki }\end{array}$ & $\begin{array}{l}\text { ethnographic } \\
\text { sea and sun }\end{array}$ & $\begin{array}{l}\text { museum } \\
\text { complex, } \\
\text { Cossack } \\
\text { farmstead }\end{array}$ & \begin{tabular}{l|} 
Cossack \\
folklore \\
festival, Day of \\
the Chebak
\end{tabular} & $\begin{array}{l}\text { horse riding, } \\
\text { Cossack crafts }\end{array}$ \\
\hline 3 & Bagaevskaya & Bagaevskaya & farm & $\begin{array}{l}\text { thematic } \\
\text { rural } \\
\text { villages }\end{array}$ & $\begin{array}{l}\text { Cucumber's } \\
\text { Day }\end{array}$ & $\begin{array}{l}\text { cooking of } \\
\text { cucumbers, } \\
\text { crop harvesting }\end{array}$ \\
\hline 4 & Belaya Kalitva & Pogorelov & ethnographic & \begin{tabular}{|l} 
typical \\
Cossack \\
stanitsas \\
\end{tabular} & Kayal readings & Cossack crafts \\
\hline 5 & Volgodonsk & Romanovskaya & $\begin{array}{l}\text { river (hunting } \\
\text { and fishing), } \\
\text { archaeological }\end{array}$ & $\begin{array}{l}\text { fishing } \\
\text { complexes, } \\
\text { larchaeologic } \\
\text { al museums }\end{array}$ & $\begin{array}{l}\text { festival of non- } \\
\text { mainstream } \\
\text { music }\end{array}$ & fishing \\
\hline 6 & Yegorlykskaya & Yegorlykskaya & farm & $\begin{array}{l}\text { farm } \\
\text { villages }\end{array}$ & harvest festival & \begin{tabular}{|l|} 
agricultural \\
works
\end{tabular} \\
\hline 7 & Zernograd & Gulyai-Borisovka & $\begin{array}{l}\text { wild-honey } \\
\text { farming }\end{array}$ & $\begin{array}{l}\text { beekeeping } \\
\text { complexes }\end{array}$ & Bees' Day & $\begin{array}{l}\text { honey } \\
\text { gathering }\end{array}$ \\
\hline 8 & KrasnyiSulin & Zaytsevka & sport & $\begin{array}{l}\text { sporting } \\
\text { complex }\end{array}$ & $\begin{array}{l}\text { region } \\
\text { spartakiada } \\
\text { games }\end{array}$ & mountaineering \\
\hline \multirow[t]{2}{*}{9} & Myasnikovskii & $\begin{array}{l}\text { Nedvigovka, } \\
\text { Tanais }\end{array}$ & archaeological & $\begin{array}{l}\text { larchaeologic } \\
\text { al museums }\end{array}$ & Tanais Day & $\begin{array}{l}\text { pot burning, } \\
\text { archery }\end{array}$ \\
\hline & & Chaltyr' & ethnographic & $\begin{array}{l}\text { excursions: } \\
\text { Armenian } \\
\text { History and } \\
\text { Traditions } \\
\end{array}$ & $\begin{array}{l}\text { Armenian } \\
\text { Culture Days }\end{array}$ & $\begin{array}{l}\text { preparing and } \\
\text { cooking } \\
\text { Armenian } \\
\text { cuisine }\end{array}$ \\
\hline 10 & Orlovskii & Orlovskii & ecological & $\begin{array}{l}\text { bird- } \\
\text { watching }\end{array}$ & $\begin{array}{l}\text { Glorified } \\
\text { Steppe Festival }\end{array}$ & $\begin{array}{l}\text { herborization, } \\
\text { wildlife } \\
\text { photography }\end{array}$ \\
\hline 11 & $\begin{array}{l}\text { Peschanokopsk } \\
\text { oye }\end{array}$ & Peschanokopskoye & $\begin{array}{l}\text { sheep- } \\
\text { breeding }\end{array}$ & $\begin{array}{l}\text { Sheep- } \\
\text { breeding } \\
\text { complexes }\end{array}$ & Herder's Day & sheepshearing \\
\hline 12 & Proletarskii & Buddyenovskaya & horse-riding & $\begin{array}{l}\text { horse-riding } \\
\text { expedition } \\
\text { "Wind in } \\
\text { Manes" }\end{array}$ & \begin{tabular}{|l|} 
Horse-Riding \\
Festival
\end{tabular} & horse-riding \\
\hline 13 & Salsk & NovyiManych & fishing & $\begin{array}{l}\text { fishing } \\
\text { complexes }\end{array}$ & Manych Day & $\begin{array}{l}\text { fishing, } \\
\text { cooking of } \\
\text { ukha (fishing } \\
\text { soup) }\end{array}$ \\
\hline 14 & Semikarakorsk & Semikarakorsk & $\begin{array}{l}\text { ethnographic } \\
\text { farm }\end{array}$ & fair & $\begin{array}{l}\text { Zakrutkinskaya } \\
\text { Spring festival }\end{array}$ & $\begin{array}{l}\text { preparing and } \\
\text { cooking Don } \\
\text { cuisine }\end{array}$ \\
\hline 15 & Ust-Donetskii & $\begin{array}{l}\text { Melikhovskaya, } \\
\text { Razdorskaya }\end{array}$ & ethnographic & \begin{tabular}{|l|} 
typical \\
Cossack \\
stanitsas
\end{tabular} & Cossack Day & $\begin{array}{l}\text { horse riding, } \\
\text { Cossack crafts }\end{array}$ \\
\hline 16 & Tsimlansk & $\begin{array}{l}\text { Tsimlansk, } \\
\text { Novotsimlyanskaya }\end{array}$ & $\begin{array}{l}\text { food and wine } \\
\text { fishing }\end{array}$ & $\begin{array}{l}\text { gourmet } \\
\text { tours }\end{array}$ & $\begin{array}{l}\text { Don Vine } \\
\text { festival }\end{array}$ & $\begin{array}{l}\text { preparing of } \\
\text { wine }\end{array}$ \\
\hline 17 & Sholokhovskii & Veshenskaya & ethnographic & \begin{tabular}{|l|} 
typical \\
Cossack \\
stanitsas
\end{tabular} & \begin{tabular}{|l|} 
Sholokhov \\
Spring festival
\end{tabular} & $\begin{array}{l}\text { horse riding, } \\
\text { Cossack crafts }\end{array}$ \\
\hline
\end{tabular}




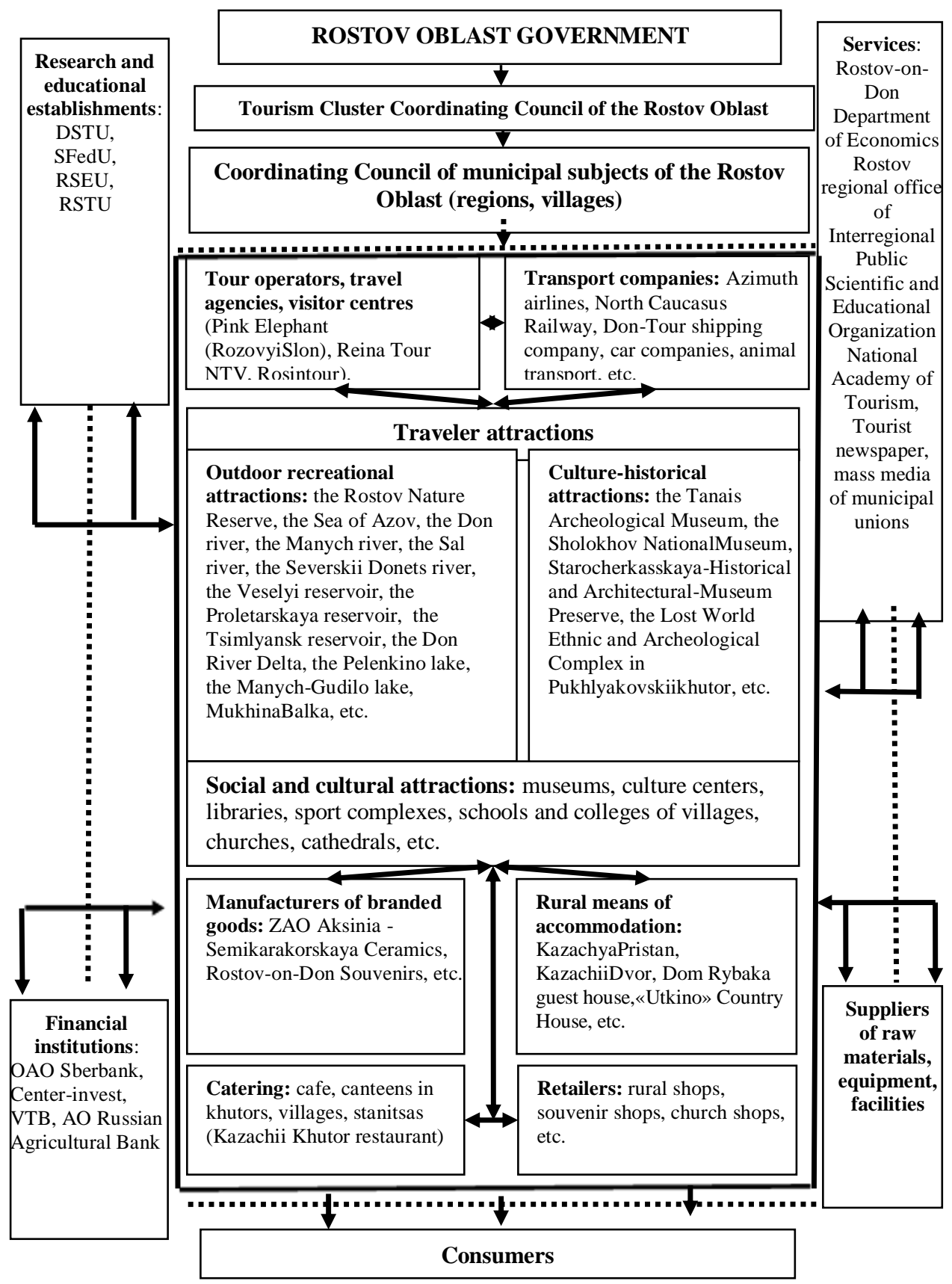

Fig.1. Structure of agritourism cluster of the Rostov region.

The scheme presents interconnections between key cluster elements - touristic facilities, service providers, transport companies, academic institution and service consumers. Municipal establishments of the region and districts are at the head of the cluster. 


\section{Discussion}

Agritourism is a driver for development of territories, a tool for generating employment and new opportunities for small and medium rural enterprises. Agritourism makes it possible to expand touristic geography within the Rostov region, to give a chance to tourists to gain unique experience. Moreover, agritourizm is a tool for sustainable development of territories. Alternative peculiar routs, thematic tours based on culture-historical and environmental aspects of specific territories, previously thought to be non-popular, will promote appearance of new unique touristic offers, season extension, and will give a chance for sustainable development of such territories

There is no unified model of tourism development: each village has to find over time its own practice, its theme and WOW moment, to determine and develop its one-of-a-kind touristic products and offers. Agritourism clustering promotes transformation of models of running businesses in this sector. Formation of agritourism business-models is influenced by such factors as historical and cultural aspects of the region, level of ecologic, social and economic development of rural territories. Distributed, concentrated and integrated models should be highlighted among traditional business-models of agritourism [23].

The distributed business-model of agritourism is based on geographical location, exceeding the specified subject (hospitality establishment, farming enterprise). This business-model requires consolidation of touristic resources, places of interest, and subjects of touristic activity. Consequently, there is no highlighting of a main service, but a final touristic product consisting of complex of accommodation, food, entertainment and destination services is offered.

As opposed to the distributed business-model, the concentrated and integrated business models of agritourism are characterized by geographical location within a specified subject of agritourism that is why specialization is a distinctive feature of these models. Distinction between these models is that enterprises operating on the basis of the concentrated business-model receive major part of profit from realization of one kind of services (for example, accommodation services, provided by hospitality establishments), whereas, in contrast, enterprises using the integrated business-model operate on the principle of horizontal diversification of services, included in a touristic product, as a base of organization and providing of services.

An example of a typical project of an agritourism object in the Rostov region based on the integrated business-model may be arrangement of the Cossack Farmstead complex. The main revenue sources are services of accommodation, food and entertainment. Guests of the complex are acquainted with time-honored Cossack culture, daily life and traditions. Infrastructure of the complex implies building of five Cossack farmsteads with capacity of 30 guests, a stylized food spot, where dishes following old Cossack recipes will be offered, stylized yard extensions, a watchtower and a Cossack redoubt. Guests of the farmstead will be provided with a wide range of additional services, such as: Cossack Living excursions, within which guests will see Cossack everyday items, take part in master classes on a rushlight holder lightening, ironing using a smoother, bringing water using a beam.

It is planned to arrange evening parties round a samovar, vareniki cooked following old recipes, Cossack songs, stable services, master classes on making dolls of cuttings, thread and clay, on willow weaving, ceramics, as well as evening animation programs.

Provided average annual occupancy of the complex of about 30-35\%, average accommodation and food bill of about 2500 rubles/a day, average stay of about 2-3 days, total annual revenues of such complexes may amount to about 9 million rubles. Payback period of such projects will not exceed 3-4 years; start-up investment amounts to 10 million rubles. 
An example of a typical project of an agritourism object in the Rostov region based on the distributed business-model may be arrangement of the Farm Tourism complex at the premises of already-existing livestock breeding and farm enterprises. Services of such complexes are not limited to accommodation in farm guest houses.

The main kind of additional services, provided in such complexes, will be:

- own organic products of livestock and crop farming products;

- exploration of agriculture: Tourists will be offered to feed animals, milk cows, collect eggs, shear sheep, be a herder and beekeeper, groom horses, ride horses and donkey, tend a garden: water plans, pluck vegetables, assist in cultivating farmland;

- wine and fermented apple juice production;

- rest in a forest: picking of mushrooms, berries and herbarium;

- activities by the side of the river;

- courses on cooking of home-made bread, cheese, farm cheese, sour cream;

- hand-made: natural accessories, ceramic goods and other traditional works of art;

- original holidays: many of them are connected to crop farming and live stock breeding (Wine Harvest, Herders' Fair).

Investment volume required to implement such a project is far below than arrangement of the Cossack Farmstead complex, based on the integrated business-model, as alreadyexisting and operating infrastructure is used. Main expenses are related to building of a farm guest house with capacity up to 20 guests and personnel training on tourist services. Provided average annual occupancy of the complex of about 40-45\%, average accommodation, entertainment and food bill of about 2000 rubles/a day, payback period of such projects will not exceed 2-3 years, being a good criteria for projects of such type.

Presented typical projects may become additional vectors of development of rural territories and reduce their dependence on agricultural complex. At the same time, such projects may attract tourists both from other districts of the region and from neighboring subjects of Russia.

\section{Conclusions}

Following the conducted research a number of conclusions can be made. Today agritourism is able to become a growth area for rural economics in the Rostov region, as development of agritourism clusters based on existing resources may be a basis for formation of a competitive touristic product.

Regulation of agritourism of the region is to performed in view of cooperation of all tiers of authority. It seems to be necessary to coordinate actions on development of tourism development programs for each municipal district oriented on tourism types, which can become a basis for development of rural territories.

Developed business-models of typical projects of agritourism may become a trigger for development of depressed territories of the region. Furthermore, they may attract additional tourist flow and become a basis for formation of a touristic brand of rural districts.

Development of agritourism may have a positive social and economic effect resulted from generating employment, increasing of gross regional product, optimization of tourist infrastructure, rise in standards and quality of life of local population.

\section{References}

1. L.V. Evgrafova,A.Z. Ismailova,V.L. Kalinichev, IOP Conference Series: Earth and Environmental Science421(2),022058 (2020)doi: 10.1088/1755-1315/421/2/022058 
2. S. Karampela, D. Kavroudakis, T. Kizos, Current Issues in Tourism22(12), 1460-1479 (2019)

3. T.Y. Dewanti, D. Susiloningtyas, IOP Conference Series: Earth and Environmental Science 335(1),012055(2019)doi: 10.1088/1755-1315/355/1/012055

4. S. Li, C. Li, J. Li,Asia Pacific Journal of Tourism Research24(11), 1079-1091 (2019)

5. N.T. Farsani, S.S. Ghotbabadi, M. Altafi, Asia Pacific Journal of Tourism Research24(6), 541-549 (2019)

6. R.M. Back, A.D.A. Tasci, A. Milman, Journal of Vacation Marketing26(1), 57-72 (2020)

7. H. Choo, J.F.Petrick,Tourism Management40, 372-381 (2014) doi: 10.1016/j.tourman.2013.07.011

8. S. Suhadi, S. Suwarni, A. Shofiyah, D.R. Putri, E.I. Diartika, N. Rizky, V.R.A. Zahroh, K.A. Widowati, IOP Conference Series: Materials Science and Engineering546(2), 0220259 (2019)

9. H. Choo, T. Jamal, Journal of Sustainable Tourism17(4), 431-454 (2009)

10. C. Barbieri, Journal of Sustainable Tourism21(2), 252-270 (2013)

11. C. Barbieri, S. Sotomayor, F.X. Aguilar,Tourism Planning and Development16(1), 4360 (2019)

12. L.O. Tugade,African Journal of Hospitality, Tourism and Leisure9(1), 1-13 (2020)

13. S. Li, C. Li, J. Li, Asia Pacific Journal of Tourism Research24(11), 1079-1091 (2019)

14. A.R.D. Liang, Y.Y. Nie, D.J. Chen, P.-J, Chen, Journal of Hospitality and Tourism Management42, 107-118 (2020)

15. M.V. Vikhoreva, Yu.N. Malanina, V.A. Ogloblin, IOP Conference Series: Earth and Environmental Science421(2), 022039 (2020)

16. M. Lanfranchi, M.G. Campolo, A.M. Di Trapani, C. Giannetto, Quality - Access to Success, 20(173), 92-94 (2019)

17. K.L. Sidali, Spitaler, G. Schamel, Sustainability (Switzerland)11(13), 3747 (2019)

18. A. Ispas, E.N. Untaru, A.N. Candrea, Sustainability (Switzerland)11(14), 38872019 (2019)

19. R.M. Back, A.D.A.Tasci,A. Milman, Journal of Vacation Marketing26(1), 57-72 (2020)

20. M. Gómez, M.A. Pratt, A. Molina, Current Issues in Tourism22(18), 2211-2249 (2019)

21. L. Hakim, D. Siswanto, B. Rahardi, H. Zayadi, EurAsian Journal of BioSciences13(2), 1613-1620 (2019)

22. L.N. Kazmina, V.S. Makarenko, V.V. Provotorina, T.N. Grigorenko, International Journal of Economics and Business Administration 7, 510-520 (2019)doi: 10.35808/ijeba/297

23. M.S. Giltsova, O.A. Mironova, Modern fundamental and applied research 1(32), 70-75 (2019)

24. A.V.Truhachev,Service in Russia and abroad 10(3),260-275(2016) doi: $10.12737 / 20116$ 